\title{
PENGARUH KOMITE AUDIT KOMISARIS INDEPENDEN DAN UKURAN KAP TERHADAP MANAJEMEN LABA PADA PERUSAHAAN MANUFAKTUR SEKTOR ANEKA INDUSTRI YANG TERDAFTAR PADA BEI TAHUN 2012-2015
}

\author{
Ganefo Sudirman \\ Universitas Pamulang \\ dosen01939@unpam.ac.id
}

\begin{abstract}
RThe research is an empirical study to examine the influence of audit committee, independent commissioner and public accounting firm size to earnings management on Indonesian Stock Exchange listed companies from manufacturing various industry sector in 2012 until 2015. The sample collected using the purposive sampling method and it has resulting 15 companies for the samples.The sample was analyzed by using linear multiple regression technique. T-test for testing the hypothesis and f-test for the feasibility model with the five percent level of significant. It was tested with classical assumption test like normality test, autocorrelation test, multicollinearity test, and heteroscedasticity test. The result shows audit committee has a negative and significant to earning management, independent commissioner committee has insignificant influence to Earnings Management, and KAP size has a positive and significant to earning management
\end{abstract}

Keywords: Audit committee, independent commissioner and public accounting firm size, earnings management

\section{PENDAHULUAN}

Munculnya konsep good corporate goverance adalah jawaban atas ketidakpuasan ilmuwan keuangan atas kinerja teori keagenan dalam tataran empirik. Bahkan unsur unsur yang membantu berlakunya good corporate governance sendiri tidak lagi berasal dari teori keagenan, yaitu : pengelola perusahaan, dewan komisaris, pemegang saham, pemberi pinjaman, remunerasi, deviden, berjalannya pasar modal, berjalannya pasar tenaga kerja manajerial, dan market for corporate control, melainkan bertambah dengan informasi, transparasi, accountability, keterbukaan dan kerahasiaan, code of conduct, jaminan hukum, dan masih akan bertambah lagi dengan investor (individu dan institusi), hak hak (hak bagi pemegang saham, hak bagi pemberi pinjaman, perangkat hukum, dan jaminan hukum). Rekayasa kinerja yang dikenal dengan istilah earnings management sejalan dengan teori keagenan (agency theory) yang menekankan pentingnya pemilik perusahaan (principles) menyerahkan pengelolaan perusahaan kepada professional (agents) yang lebih mengerti dan 
memahami cara untuk menjalankan usaha. Namun, pemisahan ini mempunyai sisi negatif, keleluasaan manajemen untuk memaksimalkan laba mengarah pada proses memaksimalkan kepentingan menejemen sendiri dengan biaya yang harus ditanggung pemilik perusahaan. Sutedi (2011:2)

Akhir-akhir ini laporan keuangan telah menjadi isu sentral, sebagai sumber penyalahgunaan informasi yang merugikan pihak-pihak yang berkepentingan. Pada tahun 1998 sampai dengan 2001 tercatat telah terjadi banyak skandal keuangan di perusahaan-perusahaan politik dengan melibatkan persoalan keuangan yang pernah diterbitkannya.Beberapa kasus yang terjadi di Indonesia, seperti PT. Lippo Tbk dan PT. Kimia Farma Tbk. juga melibatkan pelaporan keuangan (financial reporting) yang berawal dari terdeteksi adanya manipulasi. Sementara menurut beberapa media masa, lebih banyak lagi perusahaan-perusahaan non publik melakukan pelanggaran yang melibatkan persoalan laporan keuangan (Boediono, 2005).Fenomena yang terkait dalam penelitian ini yaitu terjadi pada PT Indofarma Tbk yang pernah terungkap dengan adanya kasus manajemen laba yang pernah terjadi di pasar modal Indonesia. Menurut Sulistiawan, dkk (2011:55) Kasus PT Indofarma, Tbk. merupakan kasus kekeliruan dalam penyajian laporan keuangan. Berawal dari temuan Bapepam mengenai adanya pelanggaran Undang-Undang Pasar Modal yang dilakukan oleh PT Indofarma, Tbk.

Kasus manajemen laba lainnya terjadi pada PT Kimia Farma, Tbk yang merupakan salah satu produsen obat-obatan milik pemerintah di Indonesia, pada dasarnya dimotivasi oleh keinginan pihak direksi untuk menaikan laba. Indikasi adanya pengelembungan keuntungan (overstate) dalam laporan keuangan pada semester I 2002 juga dinyatakan dalam annual report Bapepam 2002. Kesalahan penyajian dilakukan oleh direksi PT Kimia Farma dengan dua cara yaitu yang pertama direktur PT Kimia Farma mengotorisasi dua buah daftar harga persediaan pada 1 dan 3 Februari 2002 yang keduanya merupakan master pieces. Kedua, dilakukan pencatatan ganda atas penjualan. Pencatatan ganda tersebut dilakukan pada unit unit yang tidak disampling oleh akuntan sehingga tidak berhasil dideteksi. Berdasarkan hasil pemeriksaan Bapepam disimpulkan bahwa tindakan yang dilakukan oleh PT. Kimia Farma terbukti melanggar Peraturan Bapepam Nomor VIII G. 7 tentang Pedoman Penyajian Laporan Keuangan. Sulistiawan, dkk (2011:57).

Penelitian mengenai komite audit terhadap manajemen laba telah dilakukan oleh Xie, et al (2003) yang menyatakan bahwa komite audit berpengaruh negatif 
terhadap manajemen laba. Berbeda dengan hasil penelitian yang telah dilakukan oleh Guna dan Herawaty (2010) yang memperoleh hasil bahwa komite audit tidak berpengaruh terhadap manajemen laba.

Penelitian mengenai komisaris independen terhadap manajemen laba dilakukan oleh Boediono (2005) yang menyatakan komisaris independen berpengaruh terhadap manajemen laba. Berbeda dengan penelitian yang dilakukan Guna dan Herawaty (2010) yang menyatakan komisaris independen tidak berpengaruh terhadap manajemen laba. Penelitian mengenai Ukuran KAP terhadap manajemen laba dilakukan oleh Guna dan Herawaty (2010) yang menyatakan ukuran KAP berpengaruh signifikan terhadap manajemen laba. Berbeda dengan penelitian yang dilakukan oleh Veronica dan Utama (2005) menggunakan ukuran big four dan non big four sama sekali tidak menunjukkan bukti adanya pengaruh yang cukup signifikan terhadap manajemen laba.

Berdasarkan fenomena dan penelitian diatas, maka peneliti berusaha untuk menguji apakah faktor-faktor corporate governance seperti komite audit, dan komisaris independen berpengaruh terhadap manajemen laba. Selain itu, manajemen laba dalam penelitian ini diukur dengan conditional revenue model, karena menurut penelitian yang dilakukan oleh Stubben (2010) conditional revenue model lebih efektif dalam mendeteksi manajemen laba yang dilakukan oleh perusahaan. Peneliti juga menambahkan variabel independen lain yaitu ukuran KAP (Kantor Akuntan Publik) dalam penelitian ini yang bertujuan untuk menguji apakah perusahaan yang diaudit oleh KAP big four ataupun non big four mampu mendeteksi adanya manipulasi data yang dilakukan oleh pihak manajemen.

\section{TELAAH LITERATUR DAN PENGEMBANGAN HIPOTESIS}

\section{Teori Keagenan}

Dalam teori keagenan (agency theory), hubungan agensi muncul ketika satu orang atau lebih (principal) memperkerjakan orang lain (agent) untuk memberikan suatu jasa dan kemudian mendelegasikan wewenang pengambilan keputusan kepada agent tersebut. Manajer sebagai pengelola perusahaan lebih banyak mengetahui informasi internal dan prospek perusahaan di masa yang akan datang dibandingkan pemilik (pemegang saham). Oleh karena itu sebagai pengelola, manajer berkewajiban memberikan sinyal mengenai kondisi perusahaan kepada pemilik. Akan tetapi 
informasi yang disampaikan terkadang diterima tidak sesuai dengan kondisi perusahaan yang sebenarnya. Kondisi inilah yang dikenal sebagai informasi yang tidak simetris atau asimetri informasi (information asymmetric). Asimetri antara manajemen (agent) dengan pemilik (principal) dapat memberikan kesempatan kepada manajer untuk melakukan manajemen laba (Ujiyantho dan Pramuka, 2007).

Timbulnya manajemen laba dapat dijelaskan dengan teori agensi. Sebagai agen, manajer secara moral bertanggung jawab untuk mengoptimalkan keuntungan para pemilik (principal) dan sebagai imbalannya akan memperoleh kompensasi sesuai dengan kontrak. Dengan demikian terdapat dua kepentingan yang berbeda didalam perusahaan dimana masing-masing pihak berusaha untuk mencapai atau mempertahankan tingkat kemakmuran yang dikehendaki (Ali, 2002)

Munculnya permasalahan agensi antara manajer dan pemilik perusahaan, khususnya untuk perusahaan yang kepemilikannya menyebar (manager controlled). Kepemilikan seperti ini menyebabkan tidak ada pemegang saham mayoritas yang dapat mengintervensi wewenang manajer perusahaan sehingga semua pemegang saham mempunyai hak suara yang relatif sama antara satu dengan yang lain. Akibatnya, pemegang saham kesulitan dalam mengawasi dan mengendalikan manajer. Lemahnya posisi pemegang saham pada akhirnya mengakibatkan akses dan sumber terhadap informasi mengenai keuangan, manajemen, dan operasional perusahaan menjadi sangat terbatas yang dapat membuat unsur akuntabilitas dan responsibilitas informasi tidak dapat terwujud dengan baik (Sulistyanto, 2008 : 136). Teori keagenan merupakan teori yang mendasari hubungan keagenan yang menekankan adanya pemisahan kepemilikan (pemegang saham) dan pengendalian (manajemen) perusahaan. Pihak manajemen yang seharusnya melakukan tindakan yang selaras dengan kepentingan pemegang saham, dalam hal tertentu dapat bertindak untuk kepentingan sendiri sehingga menimbulkan agency problems. Adanya keterbatasan yang dimiliki pemegang saham karena tidak terlibat langsung dalam pengelolaan perusahaan menyebabkan pemegang saham tidak memiliki akses informasi yang memadai. Asimetri informasi menyebabkan agen dapat menyajikan informasi yang tidak sebenarnya pada pemegang saham. Oleh karena itu, keberadaan supervisory boards yang terdiri dari dewan komisaris dan komite audit berperan penting dalam melakukan pengawasan atas kinerja manajemen termasuk menjaga kredibilitas penyusunan laporan keuangan. (Rustiarini, 2012) 


\section{Stakeholder Theory}

Konsep Stakeholder merupakan konsep generalisasi dari gagasan pemegang saham, dimana mereka memiliki beberapa klaim khusus pada perusahaan. Teori Stakeholder menekankan pentingnya untuk mempertimbangkan kepentingan, kebutuhan, dan pengaruh dari pihak pihak yang terkait dengan kebijakan dan kegiatan operasional perusahaan, terutama dalam hal pengambilan keputusan. (Freeman, 1984)

Menutut (Sutedi, 2012: 4-8) pada prinsipnya corporate governance menyangkut kepentingan para pemegang saham, perlakuan yang sama terhadap para pemegang saham, peranan semua pihak yang berkepentingan (stakeholders) dalam corporate governance, transparasi dan penjelasan serta peranan Dewan Komisaris dan Komite Audit. Dengan tujuan untuk menciptakan nilai tambah bagi semua pihak yang berkepentingan (stakeholder). Prinsip- prinsip internasional mengenai corporate governance mulai muncul dan berkembang baru baru ini.

Stakeholder theory mengatakan bahwa perusahaan bukanlah entitas yang hanya beroperasi untuk kepentingan sendiri, namun harus memberikan manfaat bagi stakeholdernya (pemegang saham, kreditor, konsumen, supplier, pemerintah, masyarakat, analisis dan pihak lain). Dengan demikian, keberadaan suatu perusahaan sangat dipengaruhi oleh dukungan yang diberikan oleh stakeholder kepada perusahaan tersebut. Ghozali dan Chariri, (2007: 409).

\section{Corporate Governance}

Good Corporate Governance secara definitif merupakan sistem yang mengatur dan mengendalikan perusahaan untuk menciptakan nilai tambah (Value Added) untuk semua Stakeholder. Ada dua hal yang ditekankan dalam konsep ini, pertama, pentingnya hak pemegang saham untuk memperoleh informasi dengan benar (akurat) dan tepat pada waktunya dan kedua, kewajiban perusahaan untuk melakukan pengungkapan (disclosure) secara akurat, tepat waktu, dan transparan terhadap semua informasi kinerja perusahaan, kemepemilikan, dan stakeholder. Sutedi (2011:2)

Menurut Sulistyanto (2008: 138), terdapat empat prinsip - prinsip Good Corporate Governance (GCG). Prinsip - prinsip tersebut diharapkan secara konsisten dapat mewujudkan kehidupan bisnis yang sehat, bersih, dan bertanggung jawab. Keempat prinsip tersebut yaitu ; 


\section{Keadilan}

Keadilan merupakan perlindungan terhadap hak seluruh pemegang saham, termasuk pemegang saham minoritas (minority shareholder), untuk memperoleh informasi secara tepat waktu dan teratur, memberikan suara dalam rapat pemegang saham, memilih direksi dan komisaris, dan pembagian laba perusahaan. Selain itu keadilan juga menekankan pentingnya perlindungan untuk pemegang saham dari berbagai penyimpangan orang dalam perusahaan, misalnya praktik insider trading, self - dealing, keputusan manajer lain yang merugikan kepentingan seluruh pemegang saham, dan konflik kepentingan dalam menetapkan peran dan tanggung jawab dewan komisaris, manajer (direksi), dan komite, termasuk sistem remunerasi, menyajikan dan mengungkapkan informasi secara wajar.

2. Transparansi

Transparansi merupakan pengungkapan (disclosure) setiap kebijakan atau aturan yang (akan) diterapkan perusahaan, sebab kepercayaan investor dan efisiensi pasar sangat tergantung dari pengungkapan kinerja perusahaan secara adil, akurat, dan tepat waktu. Ada beberapa hal yang harus dilakukan perusahaan untuk mewujudkan prinsip ini.

a. Mengembangkan sistem akuntansi yang berbasis standar akuntansi yang diterima secara umum dan best practices yang menjamin adanya laporan keuangan dan pengungkapan yang berkualitas.

b. Mengembangkan teknologi informasi (information technology) dan sistem informasi manajemen (management information system) untuk menjamin adanya pengukuran kinerja yang memadai dan proses pengambilan keputusan yang efektif oleh komisaris dan manajer.

c. Mengembangkan manajemen risiko korporasi (enterprise risk management) untuk memastikan bahwa semua risiko telah diidentifikasi, diukur, dan dapat dikelola pada tingkat yang jelas.

d. Mengumumkan jabatan yang kosong, agar setiap pihak mengetahuinya. Hal ini dilakukan agar tidak terjadi pengangkatan pejabat perusahaan dengan cara - cara yang kolutif atau nepotisme.

\section{Akuntabilitas}

Akuntabilitas didasarkan pada sistem internal checks and balances yang mencakup praktik audit yang sehat dan dicapai melalui pengawasan yang efektif yang didasarkan pada keseimbangan kewenangan antara pemegang saham, komisaris, 
manajer, dan auditor. Ada beberapa hal yang harus dilakukan perusahaan untuk mewujudkan prinsip ini, yaitu:

a. Perusahaan dituntut untuk menyiapkan laporan keuangan pada waktu dan cara yang tepat.

b. Perusahaan harus mengembangkan komite audit dan risiko untuk mendukung fungsi pengawasan yang dijalankan oleh dewan komisaris.

c. Perusahaan harus mengembangkan dan merumuskan kembali peran dan fungsi auditor internal sebagai mitra bisnis strategis berdasarkan best practices.

d. Perusahaan harus menjaga manajemen kontrak yang bertanggung jawab dan menangani pertentangan.

e. Perusahaan harus menggunakan jasa auditor eksternal yang professional.

4. Responsibilitas

Responsibilitas merupakan tanggung jawab perusahaan untuk mematuhi hukum dan perundang - undangan yang berlaku, termasuk ketentuan mengenai lingkungan hidup, perlindungan konsumen, perpajakan, ketenagakerjaan, larangan monopoli dan praktik persaingan yang tidak sehat, kesehatan dan keselamatan kerja, dan peraturan lain yang mengatur kehidupan perusahaan dalam menjalankan aktivitas usahanya.

\section{Manajemen Laba}

Menurut Sulistiawan, dkk (2011:4) Istilah manajemen laba digunakan untuk menyebut praktik akuntansi yang tidak melanggar aturan, sedangkan istilah skandal akuntansi digunakan untuk menyebut praktik akuntansi yang melanggar aturan. Kedua istilah ini hanya diberlakukan kepada perusahaan yang secara hukum dan aturan tertentu terbukti melakukannya. Menurut Belkaoui (2006: 75) Manajemen laba terjadi ketika manajemen menggunakan pertimbangan mereka dengan tujuan menyesatkan pemangku kepentingan mengenai kondisi kinerja ekonomi perusahaan yang bergantung pada angka- angka yang dilaporkan.

\section{Komite Audit}

Menurut Sawyer, dkk (2006:512) Komite audit terdiri paling sedikit tiga orang dan tidak lebih dari enam orang anggota dewan komisaris. Dewan atau komite yang mewakili akan menunjuk para anggota dan ketua komite. Menurut Rustiarini (2012) Pengalaman merupakan faktor yang cukup penting dalam menilai kompetensi 
anggota komite audit. Anggota komite audit dapat dikatakan berpengalaman apabila pernah menduduki posisi yang sebagai konsultan, praktisi, tenaga ahli dalam bidang tertentu yang bertugas pada instansi pemerintahan, bersertifikasi akuntan publik, atau memiliki posisi sebagai Chief Executive Officer (CEO) atau senior officer lainnya yang memiliki tanggung jawab untuk bidang tertentu. Menurut Kusumastuti et al. (2007) dalam Rustiarini (2012) "Kompetensi komite audit dalam perusahaan dipengaruhi oleh tingkat pendidikan formal akademik yang dimiliki anggota komite audit. Tingkat pendidikan formal yang pernah ditempuh seseorang merupakan karakteristik kognitif yang dapat mempengaruhi cara berpikir dan kemampuan dalam pengambilan keputusan.

\section{Komisaris Independen}

Komisaris independen adalah anggota komisaris yang tidak terafiliasi dengan manajemen, anggota dewan komisaris lainnya dan pemegang saham pengendali, serta bebas dari hubungan bisnis dan hubungan lainnya yang dapat mempengaruhi kemampuannya untuk bertindak independen atau bertindak semata - mata demi kepentingan perusahaan (Guna dan Herawaty, 2010).

Dalam Peraturan OJK No 33 /POJK.04/2014 Tentang Direksi Dan Dewan Komisaris Emiten Atau Perusahaan Publik : Komisaris Independen adalah anggota Dewan Komisaris yang berasal dari luar Emiten atau Perusahaan Publik dan memenuhi persyaratan sebagai Komisaris. Dalam hal Dewan Komisaris terdiri lebih dari 2 (dua) orang anggota Dewan Komisaris, jumlah Komisaris Independen wajib paling kurang 30\% (tiga puluh persen) dari jumlah seluruh anggota Dewan Komisaris

\section{Ukuran KAP}

Audit atas laporan keuangan yang bertujuan umum di Indonesia dilakukan oleh Kantor Akuntan Publik (KAP) kecuali atas organisasi pemerintah tertentu. Hak legal untuk melakukan audit diberikan kepada Kantor Akuntan Publik oleh Menteri Keuangan. Kantor akuntan publik juga memberikan banyak jasa lain klien, seperti jasa pajak dan konsultasi. Elder (2011:35)Menurut Elder (2011:35), urutan KAP (kantor akuntan publik) yang termasuk Big Four dan berafiliasi dengan KAP yang ada di Indonesia antara lain:

1. Deloitte Touche Tohmatsu berafiliasi dengan Osman Bing Satrio \& Rekan.

2. Ernst \& Young Global berafiliasi dengan Purwanto, Sarwoko \& Sandjaja. 
3. Price Waterhouse Coopers berafiliasi dengan Haryanto Sahari \& Rekan.

4. KPMG International berafiliasi dengan Siddharta \& Wijaya.

Ukuran KAP digunakan untuk mengukur kualitas audit, dimana jika perusahaan diaudit oleh KAP Big 4 (KAP besar) maka kualitas auditnya tinggi dan jika diaudit oleh KAP Non Big 4 (KAP kecil) maka kualitas auditnya rendah (Siregar dan Utama, 2005).

\section{Pengembangan Hipotesis}

\section{Pengaruh Komite Audit terhadap Manajemen Laba}

Kompetensi merupakan salah satu kualifikasi yang seharusnya dipenuhi. Komite audit hendaknya kompeten dalam menjalankan tugas dan perannya. Bapepam mensyaratkan bahwa minimal salah satu anggota komite audit haruslah memiliki latar belakang akuntansi dan keuangan. Memiliki latar belakang akuntansi dan keuangan, atau mungkin menguasai bidang tersebut merupakan suatu karakteristik yang melambangkan kompetensi dari komite audit. Tugas komite audit pada umumnya lebih banyak berhubungan dengan proses penyusunan laporan keuangan dan audit. Oleh karena itu sangat dibutuhkan orang yang memiliki pengalaman ataupun latar belakang akuntansi dan keuangan. (Joseph dan Wardhani, 2010).

Agar komite audit dapat menjalankan tugasnya dengan efektif, anggota komite audit harus memiliki kompetensi yang dalam penelitian ini diasosiasikan dari independensi, latar belakang pendidikan, keahlian dalam bidang akuntansi dan keuangan, serta pengalaman kerja dalam hal bisnis dan industri. (Rustiarini, 2012). Menurut penelitian yang dilakukan oleh Setiawan (2009) dan Rustiarini (2012) komite audit berpengaruh negatif terhadap manajemen laba. Jika anggota komite audit memiliki latar belakang pendidikan akuntansi dan keuangan, maka pengawasan terhadap pelaporan keuangan akan menjadi baik. Dengan dasar akuntansi dan keuangan yang dimiliki oleh komite audit, seorang komite audit dapat mendeteksi adanya unsur manajemen laba dalam perusahaan. Semakin besar komposisi komite audit yang memiliki latarbelakang akuntansi dan keuangan maka tingkat manajemen laba perusahaan akan semakin rendah.

H1 : Komite audit berpengaruh negatif terhadap Manajemen Laba 


\section{Pengaruh Komisaris Independen Terhadap Manajemen Laba}

Karakteristik dewan komisaris secara umum dan khususnya komposisi dewan dapat menjadi suatu mekanisme yang menentukan tindakan manajemen laba. Melalui peranan dewan dalam melakukan fungsi pengawasan terhadap operasional perusahaan oleh pihak manajemen, komposisi dewan komisaris dapat memberikan kontribusi yang efektif terhadap hasil dari proses penyusunan laporan keuangan yang berkualitas atau kemungkinan terhindar dari kecurangan laporan keuangan. Dapat dikatakan bahwa komposisi dewan komisaris yang terdiri dari anggota yang berasal dari luar perusahaan mempunyai kecenderungan mempengaruhi manajemen laba. (Boediono, 2005)

Kemampuan dewan komisaris untuk mengawasi merupakan fungsi yang positif dari porsi dan independensi dari dewan komisaris eksternal. Dewan komisaris juga bertanggung jawab atas kualitas laporan yang disajikan. (Siallagan dan Mahfoedz, 2003). Dengan makin banyak anggota komisaris independen maka proses pengawasan yang dilakukan dewan ini makin berkualitas dengan makin banyaknya pihak independen dalam perusahaan yang menuntut adanya transparansi dalam pelaporan keuangan perusahaan. (Nasution dan Setiawan, 2007).

H2 : Komisaris Independen berpengaruh negatif terhadap Manajemen Laba

\section{Pengaruh Ukuran KAP terhadap Manajemen Laba}

De Angelo (1981) menyatakan bahwa kualitas auditor dapat dilihat dari dua dimensi, pertama auditor harus mampu mendeteksi salah saji material, kedua salah saji tersebut harus dilaporkan. Kemampuan untuk mendeteksi salah saji material sangat dipengaruhi oleh kemampuan teknologi dari auditor, prosedur audit dan jumlah sampling.

KAP big four memiliki sumber daya manusia yang lebih baik dari pada KAP non big four. Hal ini dapat dilihat dari seleksi masuk KAP big four yang lebih sulit dibandingkan dengan KAP non big four. Dengan pemilihan auditor yang selektif maka auditor yang bekerja di KAP big four memiliki kompentensi dan kemampuan yang baik sehingga dapat menekan auditee untuk tidak melakukan praktik manejemen laba. Semakin baik kualitas auditor maka akan mengurangi manajemen laba yang dilakukan oleh perusahaan, sebaliknya jika kualitas audit rendah, maka 
akan memungkinkan tidak teridentifikasinya salah saji material yang dengan sengaja dilakukan oleh auditee untuk menaikan atau menurunkan laba.

H3 : Ukuran KAP berpengaruh negatif terhadap Manajemen Laba

\section{METODE PENELITIAN DAN PEMBAHASAN}

\section{Operasional Variabel}

\section{Variabel Dependen}

\section{Manajemen Laba}

Manajemen laba merupakan suatu intervensi dengan maksud tertentu terhadap proses pelaporan keuangan eksternal dengan sengaja untuk memperoleh beberapa keuntungan pribadi. (Schipper, 1989).

Dalam penelitian ini manajemen laba diproksikan dengan discresionary Revenue (DR) (Stubben, 2010) dengan formula sebagai berikut :

$\Delta$ ARit $=\alpha+\beta 1 \Delta$ Rit $+\beta 2 \Delta$ Rit $\times$ SIZEit $+\beta 3 \Delta$ Rit $\times$ AGE it $+\beta 4 \Delta$ Rit $\times$ AGE_SQ it

$+\beta 5 \Delta$ Rit $\times$ GRR_Pit $+\beta 6 \Delta$ Rit $\times$ GRR_Nit $+\beta 7 \Delta$ Rit $\times$ GRMit $+\beta 8$ $\Delta$ Rit $\times$ GRM_SQit $+\varepsilon$ it

Keterangan :

$\Delta \mathrm{AR} \quad=$ piutang akrual

$\mathrm{R}=$ annual revenue

SIZE = natural log dari total aset saat akhir tahun

AGE = natural log umur perusahaan

GRR_P = industry median adjusted revenue growth (=0 if negative)

GRR_N = industry median adjusted revenue growth (= 0 if positif)

GRM = industry median adjusted gross margin at end of fiscal year

_SQ $\quad=$ square of variable

$\Delta \quad=$ annual change

\section{Variabel Independen}

\section{Komite Audit}

Komite audit adalah komite dibawah dewan komisaris yang terdiri dari sekurang kurangnya seorang komisaris independen dan para profesional independen dari 
luar perusahaan, yang tanggung jawabnya termasuk membantu para auditor tetap independen dari manajemen. Elder, dkk (2011:84). Berikut adalah pengukuran dari Komite audit :

\section{Komisaris Independen}

Komisaris independen adalah anggota komisaris yang tidak terafiliasi dengan manajemen, anggota dewan komisaris lainnya dan pemegang saham pengendali, serta bebas dari hubungan bisnis dan hubungan lainnya yang dapat mempengaruhi kemampuannya untuk bertindak independen atau bertindak semata - mata demi kepentingan perusahaan. (Guna dan Herawaty, 2010). Berikut adalah pengukuran dari Komisaris Independen :

\section{Ukuran KAP}

Ukuran KAP digunakan untuk mengukur kualitas audit, dimana jika perusahaan diaudit oleh KAP Big 4 (KAP besar) maka kualitas auditnya tinggi dan jika diaudit oleh KAP Non Big 4 (KAP kecil) maka kualitas auditnya rendah. Ukuran KAP dalam penelitian ini diukur dengan menggunakan variabel dummy. Dimana angka 1 digunakan untuk mewakili perusahaan yang diaudit oleh KAP big four dan angka 0 digunakan untuk mewakili perusahaan yang diaudit oleh KAP non big four. (Siregar dan Utama, 2008)

\section{Variabel control}

\section{Ukuran Perusahaan}

Variabel ini diukur dengan dari nilai logaritma total assets perusahaan (Wardhani dan Joseph, 2010)

\section{Leverage}

Diukur dengan perbandingan antara total kewajiban dengan total aktiva perusahaan. Rasio ini menunjukan besarnya besar aktiva yang dimiliki perusahaan yang dibiayai dengan hutang. (Pambudi dan Sumantri, 2014)

\section{Populasi dan Sampel Penelitian}

\section{Populasi}

Populasi yang akan digunakan menjadi objek dalam penelitian ini adalah perusahaan manufaktur go public sektor aneka industri yang terdaftar di Bursa Efek Indonesia (BEI) dan menerbitkan laporan keuangan tahunan (annual report) yang 
diterbitkan BEI untuk periode 2012, 2013, 2014 dan 2015. Dimana perusahaan tersebut mempublikasikan laporan keuangannya ke BEI yang telah diaudit oleh auditor independen.

\section{Sampel Penelitian}

Teknik penentuan sampel yang akan digunakan dalam penelitian ini mengunakan metode purposive sampling yaitu menentukan sampel yang telah memenuhi kriteria sesuai dengan yang diinginkan dan kemudian dipilih melalui pertimbangan yang dikehendaki untuk tujuan penelitian. Adapun perusahaan yang menjadi sampel dalam penelitian ini dipilih berdasarkan kriteria - kriteria tertentu, yaitu sebagai berikut:

1. Perusahaan manufaktur sektor aneka industri yang terdaftar di BEI selama periode pengamatan untuk periode 2012, 2013, 2014 dan 2015.

2. Perusahaan yang mempublikasikan laporan tahunan untuk periode yang berakhir 31 Desember 2012 - 2015 yang dinyatakan dalam rupiah dan lengkap.

3. Memiliki data profil komite audit dan komisaris independen lengkap.

4. Tidak Merger dan Akuisisi pada periode yang berakhir 31 Desember 2012- 2015.

\section{Metode Analisis Data}

Teknik analisis data yang digunakan dalam penelitian ini adalah dengan menggunakan analisis regresi berganda (Multiple Regression Analyst). Analisis regresi linier berganda adalah hubungan secara linier antara dua atau lebih variabel dependen yang digunakan untuk memprediksi atau meramalkan suatu nilai variabel dependen berdasarkan variabel independen (Priyatno, 2012: 80).

Persamaan regresi yang digunakan dalam penelitian ini adalah:

$\mathrm{DR}=\beta \_0+\beta \_1 \mathrm{KA}+\beta \_2 \mathrm{KI}+\beta \_3 \mathrm{KAP}+\beta \_4 \mathrm{UP}+\beta \_5 \mathrm{LEV}+\mathrm{e}$

Keterangan :

DR : Manajemen Laba

KA : Komite Audit

KI : Komisaris Independen

KAP : Ukuran KAP

UP : Ukuran Perusahaan

LEV : Leverage

e : error 


\section{Analisis Statistik Deskriptif}

Berdasarkan hasil pengolahan data dengan bantuan SPSS (Statistical Product and Service Solution) 23.0 diperoleh hasil perhitungan sebagai berikut

Tabel Statistik Deskriptif

Descriptive Statistics

\begin{tabular}{|l|r|r|r|r|r|}
\hline & \multicolumn{1}{|c|}{$\mathrm{N}$} & Minimum & Maximum & \multicolumn{1}{|c|}{ Mean } & Std. Deviation \\
\hline Manajemen Laba & 60 &,- 06 &, 10 &, 0000 &, 02945 \\
Komite Audit & 60 &, 33 & 1,00 &, 6383 &, 17880 \\
Komisaris Independen & 60 &, 25 &, 67 &, 4130 &, 11655 \\
Ukuran Perusahaan & 60 & 25,32 & 30,84 & 27,8199 & 1,36370 \\
Leverage & 60 &, 22 & 3,03 &, 7148 &, 60295 \\
Valid N (listwise) & 60 & & & & \\
\hline
\end{tabular}

Berdasarkan tabel diatas, jumlah sampel dalam penelitian ini sebanyak 60 sample dari 15 perusahaan selama 4 tahun, dimulai dari tahun 2012 sampai dengan tahun 2015. Diketahui bahwa nilai rata-rata variabel Manajemen Laba adalah sebesar 0.0000 dengan jumlah sampel sebanyak 60. Ini berarti secara rata rata perusahaan manufaktur sektor aneka industri tidak melakukan manajemen laba yang signifikan. Variabel Manajemen Laba ini memiliki nilai minimum sebesar -0.06 yang berasal dari PT. Gajah Tunggal, Tbk pada tahun 2012. Nilai sebesar -0,06 memiliki arti bahwa PT. Gajah Tunggal, Tbk pada tahun 2012 melakukan Pola income mimimization untuk tujuan tertentu, misalnya untuk menekan jumlah pajak terutang pada tahun 2012. Sedangkan nilai maksimum sebesar 0.10 berasal dari PT. Sepatu Bata, Tbk pada tahun 2014 yang menunjukan bahwa perusahaan ini melakukan pola income maximization yang cenderung untuk meningkatkan kinerja perusahaan. Standar deviasi untuk variabel ini sebesar 0.02945, artinya data tidak terlalu menyebar.

Variabel Komite audit memiliki nilai rata-rata sebesar 0.6383. Artinya secara rata rata anggota komite audit yang berlatar belakang pendidikan akuntansi dan keuangan di perusahaan aneka industri rata rata 2 orang dari 3 komite audit. Nilai 
minimum sebesar 0.33 berasal dari PT. Panasia Indo Resources Tbk Tahun 2012, PT. Kabelindo Murni, Tbk Tahun 2012, 2013, dan 2014, PT. Nippres, Tbk Tahun 2012, PT. Ricky Putra Globalindo, Tbk Tahun 2012 dan 2013 dan PT. Nusantara Inti Corpora Tbk Tahun 2012, 2013, 2014 dan 2015. Nilai minimum sebesar 0.33 artinya jika dari jumlah 3 orang anggota komite audit hanya ada satu yang berlatar belakang akuntansi dan keuangan, maka proses pengawasan dalam proses pelaporan keuangan perusahaan menjadi tidak maksimal. Sedangkan nilai maksimum sebesar 1.00 berasal dari PT. Gajah Tunggal Tbk Tahun 2012, 2013, 2014 dan 2015 dan PT. Ricky Putra Globalindo, Tbk Tahun 2014 dan 2015. Artinya perusahaan memaksimalkan pengawasan terhadap proses pelaporan keuangan dengan memilih komite audit yang berlatar belakang akuntansi dan keuangan. Standar deviasi untuk variabel ini sebesar 0.17880 , artinya data tidak terlalu menyebar.

Variabel Komisaris Independen memiliki nilai rata-rata sebesar 0.4130. Artinya hanya kurang lebih 1 dari 3 komisaris yang merupakan komisaris independen dan hanya sekedar memenuhi peraturan yang dibuat oleh Otoritas jasa keuangan. Nilai minimum sebesar 0.25 berasal dari PT. Panasia Indo Resources, Tbk Tahun 2012. Nilai minimum ini belum melanggar ketentuan dari OJK karena peraturan minimal komisaris independen sebesar 30\% baru diberlakukan sejak tahun 2014 sesuai dengan POJK No 33 /POJK.04/2014 Tentang "Direksi Dan Dewan Komisaris Emiten Atau Perusahaan Publik". Sedangkan nilai maksimum sebesar 0.67 berasal dari PT. Primarindo Asia Infrastructure, Tbk Tahun 2012, 2013, 2014 dan 2015 serta PT. Jembo Cable Company Tbk Tahun 2012, 2013, 2014 dan 2015. Artinya manajemen ingin memaksimalkan pengawasan terhadap operasional perusahaan dan proses pelaporan keuangan dengan menambah proporsi komisaris independen dalam jajaran dewan komisaris. Standar deviasi untuk variabel ini sebesar 0.11655, artinya data tidak terlalu menyebar.

Variabel Ukuran Perusahaan memiliki nilai rata rata sebesar 27.8119. Nilai minimum sebesar 25.32 atau sebesar 99.558.394.760 berasal dari PT. Primarindo Asia Infrastructure, Tbk Tahun 2015. Sedangkan nilai maksimum sebesar 30.84 atau sebesar 24.860.957.839.497 berasal dari PT. Indomobil Sukses International, Tbk pada tahun 2015. Standar deviasi untuk variabel ini sebesar 1.3637, artinya data tidak terlalu menyebar.

Variabel leverage memiliki nilai rata rata sebesar 0.71384 . Artinya secara rata rata perusahaan manufaktur sektor industri memiliki sumber pembiayaan $71 \%$ dari 
utang dan 29\% dari modal sendiri ditambah saldo laba ditahan. Nilai minimum sebesar 0.22 berasal dari PT. Panasia Indo Resources, Tbk tahun 2015 artinya jumlah modal sendiri ditambah laba ditahan sebesar $78 \%$ dari total aset. Sedangkan nilai maksimum sebesar 3.03 berasal dari PT. Primarindo Asia Infrastructure, Tbk tahun 2015 artinya modal sendiri ditambah dengan laba ditahan negatif 300\% yang diakibatkan kerugian yang diaalami perusahaan secara terus menerus tiap tahunnya. Standar deviasi untuk variabel ini sebesar 0.60295, artinya data tidak terlalu menyebar.

Sedangkan variabel Ukuran KAP tidak diikutsertakan dalam analisa statistik deskriptif karena Ukuran KAP merupakan variabel yang menggunakan skala nominal dan tidak memiliki nilai sehingga tidak dapat dihitung rata-rata (mean) dan standar deviasinya. Variabel yang berskala nominal dapat dideskripsikan menggunakan frequency table berikut ini :

\section{Tabel Frekuensi Ukuran KAP}

Ukuran KAP

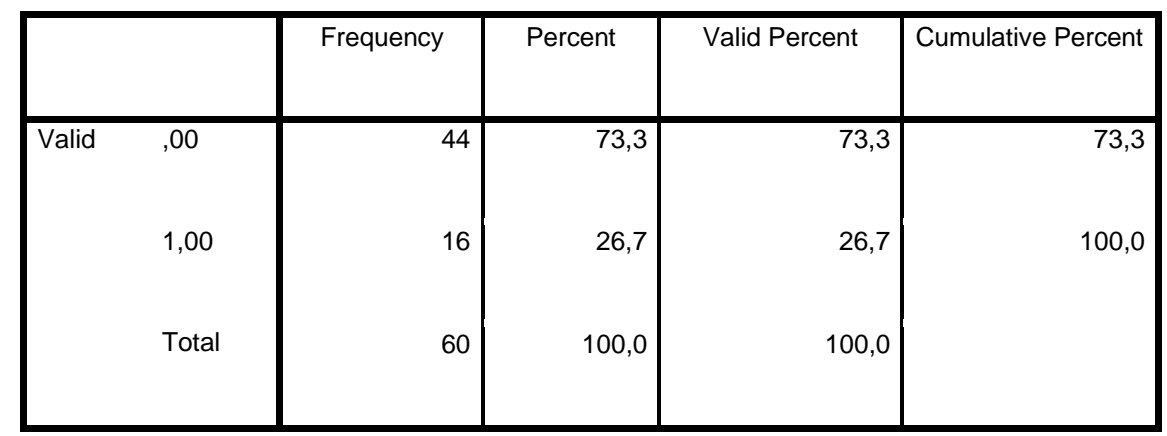

Penilaian Ukuran KAP dalam penelitian ini menggunakan latar belakang kantor akuntan publik (KAP) big 4 dan non big 4. Sehingga angka 1 untuk laporan keuangan yang diaudit oleh kantor akuntan big 4, sedangkan angka 0 untuk laporan keuangan yang diaudit oleh kantor akuntan non big 4 .

\section{Uji Asumsi Klasik}

\section{Uji Normalitas}

Dari gambar 4.1 di bawah ini terlihat bahwa data menyebar mengikuti garis diagonal, maka model regresi ini memenuhi asumsi normalitas.

Grafik Hasil Uji Normalitas 


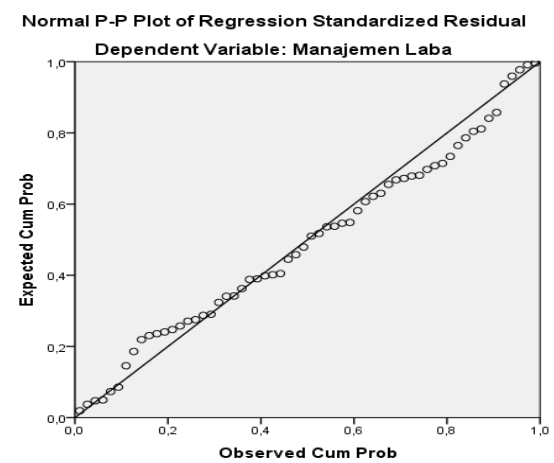

Uji normalitas dengan grafik dapat menyesatkan kalau tidak hati-hati secara visual terlihat normal, padahal secara statistik bisa sebaliknya (Ghozali, 2013: 163). Oleh karena itu, diperlukan uji statistik yaitu uji Kolmogorov-Smirnov (K-S). Jika nilai signifikansi > 0.05 maka data tersebut berdistribusi normal. Berikut ini tabel yang menjelaskan mengenai uji Kolmogorov-Smirnov.

\begin{tabular}{|c|c|c|}
\hline & & $\begin{array}{c}\text { Unstandardized } \\
\text { Residual }\end{array}$ \\
\hline $\mathrm{N}$ & & 60 \\
\hline \multirow[t]{2}{*}{ Normal Parameters ${ }^{\mathrm{a}, \mathrm{b}}$} & Mean &, 0000000 \\
\hline & Std. Deviation & ,02567201 \\
\hline \multirow[t]{3}{*}{ Most Extreme Differences } & Absolute & ,077 \\
\hline & Positive &, 077 \\
\hline & Negative &,- 076 \\
\hline Test Statistic & & ,077 \\
\hline Asymp. Sig. (2-tailed) & &, $200^{\mathrm{c}, \mathrm{d}}$ \\
\hline
\end{tabular}

Dari tabel diatas dapat dilihat bahwa hasil uji Kolmogorov-Smirnov sebesar 0.077 dengan nilai signifikansi sebesar 0.200. Hasil ini menunjukkan bahwa data residual terdistribusi secara normal karena nilai signifikan $>0.05$ maka hasil ini konsisten dengan analisis grafik pada pengujian sebelumnya yang menyatakan model regresi memenuhi asumsi normalitas.

\section{Uji Autokorelasi}

Uji autokorelasi bertujuan menguji apakah dalam model regresi linear ada korelasi antara kesalahan pengganggu pada periode t-1 (sebelumnya). Jika terjadi korelasi, maka dinamakan ada problem autokorelasi. Autokorelasi muncul karena observasi yang berurutan sepanjang waktu berkaitan satu sama lainnya. Hal ini sering 
ditemukan pada data runtut waktu (time series) karena "gangguan" pada individu/kelompok yang sama pada periode berikutnya (Ghozali, 2013: 110). Uji autokorelasi dilakukan dengan melihat nilai Durbin-Watson (DW).

Model Summary

\begin{tabular}{|l|r|}
\hline Model & Durbin-Watson \\
\hline 1 & 2.210 \\
\hline
\end{tabular}

Berdasarkan hasil uji autokorelasi pada tabel diatas terlihat nilai DurbinWatson sebesar 2.210. Menurut tabel durbin Watson, tidak terdapat autokorelasi jika nilai du $<\mathrm{d}<4$-du. Sehingga didapat bahwa $1.767<2.210<4-1.767$, disimpulkan bahwa model regresi ini tidak terdapat masalah autokorelasi.

\section{Uji Heteroskedastisitas}

Uji heteroskedastisitas bertujuan untuk menguji apakah dalam model regresi terjadi ketidaksamaan variance dari residual satu pengamatan ke pengamatan lain. Jika variance dari residual satu pengamatan ke pengamatan lain tetap, maka disebut Homoskedastisitas dan jika berbeda disebut Heteroskedastisitas. Model regresi yang baik adalah yang Homoskedastisitas atau tidak terjadi Heteroskedastisitas (Ghozali, 2013: 139). Pengujian ini dapat dilihat dari gambar grafik Scatterplots dibawah ini.

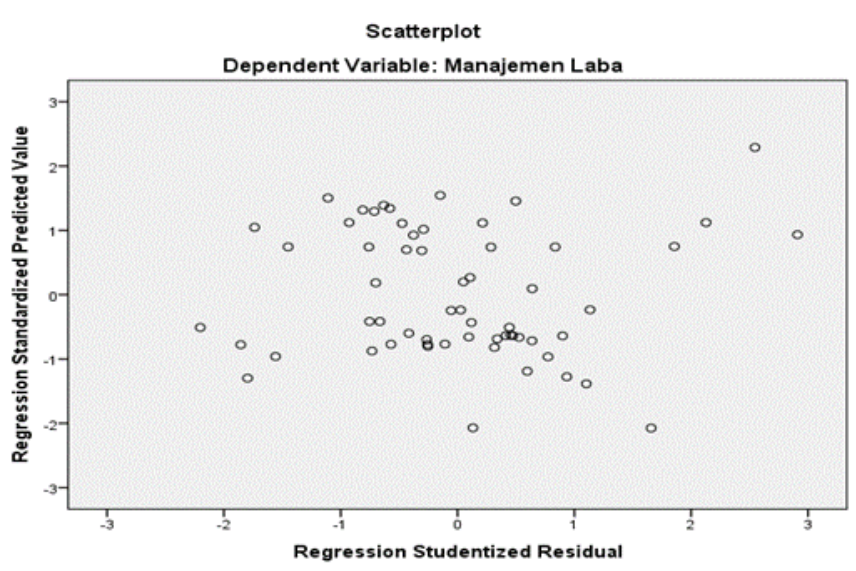

Berdasarkan grafik Scatterplot pada gambar 4.2 diatas terlihat bahwa titik-titik menyebar secara acak dan tidak membentuk sebuah pola tertentu yang jelas, serta tersebar baik di atas maupun dibawah angka 0 pada sumbu Y. Hal ini berarti menunjukkan bahwa tidak terjadinya Heteroskedastisitas pada model regresi ini. 


\section{Uji Multikolonieritas}

Uji Multikolonieritas bertujuan untuk menguji apakah model regresi ditemukan adanya korelasi antara variabel bebas (independen). Model regresi yang baik seharusnya tidak terjadi korelasi di antara variabel independen. Pendeteksiannya dilakukan dengan menggunakan tolerance value dan VIF (variance inflation factor). Jika nilai tolerance value $>0,10$ dan $\mathrm{VIF}<10$ maka tidak terjadi multikolonieritas (Ghozali, 2011: 105).

\begin{tabular}{|c|c|c|}
\hline \multirow[b]{2}{*}{ Model } & \multicolumn{2}{|c|}{ Collinearity Statistics } \\
\hline & Tolerance & VIF \\
\hline $1 \quad$ (Constant) & & \\
\hline Komite Audit & ,750 & 1,333 \\
\hline Komisaris Independen &, 577 & 1,733 \\
\hline Ukuran KAP & ,639 & 1,565 \\
\hline Ukuran Perusahaan &, 558 & 1,792 \\
\hline Leverage &, 530 & 1,887 \\
\hline
\end{tabular}

Dari tabel diatas, dapat diketahui bahwa nilai Variance Inflation Factor (VIF) dari masing-masing variabel independen tidak memiliki nilai yang lebih dari 10 dan tolerance value $>0.10$, sehingga hal ini menandakan bahwa model regresi yang terdapat di dalam penelitian ini tidak mengandung multikolonieritas.

\section{Hasil Pengujian Hipotesis}

\section{Uji F}

Uji F pada dasarnya menunjukkan apakah semua variabel independen atau bebas yang dimasukkan dalam model mempunyai pengaruh secara bersama-sama terhadap variabel dependen/terikat (Ghozali, 2013: 98).

ANOVA $^{\mathrm{a}}$

\begin{tabular}{|l|r|r|r|r|r|}
\hline Model & Sum of Squares & Df & Mean Square & F & Sig. \\
\hline 1 Regression &, 012 & 5 &, 002 & 3,410 &, $009^{\mathrm{b}}$ \\
Residual &, 039 & 54 &, 001 & & \\
Total &, 051 & 59 & & & \\
\hline
\end{tabular}

Dengan menggunakan tabel distribusi F diperoleh Ftabel sebesar $2.39<$

Fhitung 3.410 dengan tingkat signifikansi sebesar $0.009<0.05$. Dengan demikian, 
dapat disimpulkan bahwa komite audit, komisaris independen, ukuran KAP, ukuran perusahaan dan leverage secara simultan berpengaruh signifikan terhadap manajemen laba.

\section{Uji R2 (Uji Koefisien Determinasi)}

Uji R2 (Uji Koefisien Determinasi) berguna untuk mengukur seberapa variabel independen (komite audit, komisaris independen, ukuran KAP) dan variabel control (Ukuran Perusahaan dan Leverage) mempengaruhi perubahan yang terjadi pada variabel dependen (Manajemen Laba).

Model Summary

\begin{tabular}{|l|r|r|r|r|}
\hline Model & R & R Square & Square & $\begin{array}{c}\text { Adjusted R } \\
\text { Estimate }\end{array}$ \\
\hline 1 &, $490^{\mathrm{a}}$ &, 240 &, 170 &, 02683 \\
\hline
\end{tabular}

Tabel diatas menunjukkan bahwa nilai adjusted R Square (R2) adalah sebesar 0.17 atau $17 \%$. Sehingga hal ini menunjukkan bahwa persentase pengaruh variabel independen (Komite Audit, Komisaris Independen, Ukuran KAP) dan variabel control (Ukuran Perusahaan dan Leverage) terhadap variabel dependen (Manajemen Laba) sebesar 17\%, sisanya $83 \%$ dipengaruhi oleh variabel lain yang tidak dimasukkan kedalam penelitian ini atau faktor-faktor lain yang lebih dominan.

\section{Pembahasan Hasil Penelitian}

Berdasarkan hasil analisis statistik deskriptif dan pengujian regresi linear berganda tentang pengaruh komite audit, komisaris independen, dah ukuran KAP terhadap manajemen laba dengan ukuran perusahaan dan leverage sebagai variabel kontrol sebagai berikut:

1. Pengaruh komite audit terhadap manajemen laba

Berdasarkan hasil uji t (parsial) menunjukkan bahwa komite audit dengan koefisien regresi sebesar -0.067 dan tingkat signifikansi sebesar 0.0048, maka dapat disimpulkan komite audit berpengaruh negatif terhadap manajemen laba. Kondisi ini menandakan bahwa semakin tinggi proporsi komite audit yang berlatar belakang pendidikan akuntansi dan keuangan dalam suatu perusahaan akan mengurangi manajemen laba yang terjadi. Hal ini dikarenakan berdasarkan data yang diteliti rata rata jumlah komite audit yang berlatar belakang akuntansi dan 
keuangan sebesar $0.64 \%$ artinya lebih dominan komite audit yang memiliki latar belakang akuntansi dan keuangan dibandingkan dengan yang tidak berlatatar belakang pendidikan selain akuntansi dan keuangan.

Berdasarkan hasil ini menunjukan bahwa peraturan yang dibuat oleh pemerintah berhasil mengurangi tingkat manajemen laba. Komite audit yang memiliki latar belakang akuntansi dan keuangan mampu mendeteksi manajemen laba yang dilakukan oleh pihak manajemen perusahaan dengan mengawasi proses pelaporan keuangan. Penelitian ini mendukung penelitian terdahulu yang dilakukan oleh Xie et al. (2003), Setiawan (2009), Rustiarini (2012) komite audit berpengaruh negatif terhadap manajemen laba. Hasil penelitian ini tidak sejalan dengan penelitian yang dilakukan oleh Siregar dan Utama (2008), Utami dan Rahmawati (2008) dan Habbash, et al (2012) dimana keberadaan komite audit tidak memiliki pengaruh terhadap manajemen laba yang dilakukan oleh perusahaan.

2. Pengaruh komisaris independen terhadap manajemen laba

Hasil uji t (parsial) terkait variabel komisaris independen dengan koefisien regresi sebesar -0.037 dan tingkat signifikansi sebesar 0.359 menunjukkan bahwa komisaris independen tidak berpengaruh terhadap manajemen laba. Semakin besar proporsi komisaris independen dalam suatu perusahaan maka tidak dapat mengurangi praktik manajemen laba. Hal ini dikarenakan berdasarkan data yang diteliti hanya sebesar $41 \%$ proporsi komisaris independen dalam jajaran dewan komisaris, sehingga keberadaan komisaris independen hanya untuk pemenuhan syarat yang ditetapkan oleh Otoritas Jasa Keuangan.

Peran komisaris utama dan komisaris perusahaan yang lebih dominan dalam membuat dan menentukan kebijakan dalam jajaran dewan komisaris yang lebih memprioritaskan kepentingan perusahaan. Untuk mendeteksi manajemen laba, komisaris independen harusnya memiliki kontribusi maksimal dalam melakukan pengawasan proses pelaporan keuangan perusahaan walaupun secara jumlah lebih sedikit dibandingkan dengan komisaris perusahaan.

Penelitian ini mendukung penelitian terdahulu yang dilakukan oleh Boediono (2005), Ujiyantho dan Pramuka (2007) dan Setiawan (2009). Dimana komisaris independen tidak berpengaruh terhadap manajemen laba. Hasil penelitian ini tidak sejalan dengan penelitian yang dilakukan Xie et al. (2003), Nasution dan Setiawan 
(2007) dan Utami dan Rahmawati (2008) dimana komisaris independen berpengaruh negatif terhadap manajemen laba.

3. Pengaruh ukuran KAP terhadap manajemen laba

Hasil uji t (parsial) terkait variabel ukuran KAP dengan koefisien regresi sebesar 0.032 dan tingkat signifikansi sebesar 0.002 menunjukkan bahwa ukuran KAP berpengaruh signifikan terhadap manajemen laba. Semakin baik kualitas auditor akan meningkatkan manajemen laba perusahaan. Secara langsung Kantor Akuntan Publik tidak memiliki tanggung jawab untuk mendeteksi manajemen laba, tetapi bertanggungjawab atas opini audit dan memastikan laporan keuangan disajikan secara wajar dan bebas dari salah saji material. Maka dari itu secara tidak langsung KAP harus memastikan semua akun yang tercatat dalam laporan keuangan bebas dari salah saji yang material. Permasalahannya adalah dalam menentukan materialitas, setiap KAP memiliki kebijakan yang berbeda satu sama lain dalam menentukan batas materialitas.

Dalam proses audit, auditor harus memastikan tidak ada transaksi fiktif yang dilakukan perusahaan. Salah satu prosedur yang dilakukan untuk mendeteksi manajemen laba adalah cut off atau pisah batas, prosedur ini dilakukan untuk memastikan bahwa perusahaan telah mencatat transaksi sesuai dengan periode pelaporan. Jika dalam proses audit auditor menemukan kesalahan baik dilakukan secara sengaja atau karena ketidaktahuan, maka auditor harus membuat management letter yang isinya mengenai kelemahan, kesalahan, dan kecurangan yang dilakukan oleh perusahaan. Tidak selalu dilakukan koreksi atas kesalahan dan kecurangan tersebut karena koreksi atas kesalahan atau kecurangan tersebut dilakukan sesuai dengan professional adjustment yang dinilai oleh auditor di masing masing KAP tersebut.

KAP big 4 melakukan audit secara efektif dimana jika selisih atau perbedaan atas substantive test melebihi batas materialitas yang telah ditentukan dalam audit plan, maka atas selisih tersebut dilakukan adjustment. Sebaliknya jika selisih tidak melebihi batas materialitas, maka tidak perlu dilakukan adjustment. Manajemen laba dianggap wajar jika tidak melebihi batas materialitas. Sebaliknya KAP non Big 4 cenderung melakukan adjustment untuk setiap selisih atas substantive test sehingga manajemen tidak bisa secara melakukan manajemen laba. 
Jika dilihat dari sampel penelitian, hanya 16 sampel dimana perusahaan menggunakan KAP big 4 untuk melakukan audit tahunan. Selain itu nilai minimum variabel manajemen laba sebesar -0.06 yang berasal dari PT. Gajah Tunggal, Tbk pada tahun 2012 dan nilai maksimum sebesar 0.10 berasal dari PT. Sepatu Bata, Tbk pada tahun 2014 dimana keduanya diaudit oleh KAP big 4. Manajemen laba yang dilakukan kedua sampel ini mungkin dibawah batas materialitas sehingga KAP memiliki keyakinan bahwa tidak ada salah saji yang material dalam laporan keuangan tersebut dan manajemen laba yang dilakukan oleh perusahaan tersebut dianggap wajar.

Hasil ini sejalan dengan fenomena yang terjadi pada PT Kimia Farma, Tbk., dimana KAP Hans Tuanakota dan Mustofa yang merupakan KAP big 4 tidak mampu mendeteksi adanya manajemen laba dalam perusahaan tersebut. Hal ini disebabkan manajemen laba yang dilakukan oleh PT Kimia Farma, Tbk. dianggap bebas dari salah saji yang material karena dibawah batas materialitas. Hasil penelitian ini tidak sejalan dengan penelitian yang dilakukan oleh Siregar dan Utama (2008) dan Utami dan Rahmawati (2008) dimana ukuran KAP tidak berpengaruh terhadap manajemen laba.

4. Pengaruh ukuran perusahaan terhadap manajemen laba

Hasil uji t (parsial) terkait variabel ukuran perusahaan menunjukan koefisien regresi sebesar -0.004 dan tingkat signifikansi sebesar 0.288 yang menunjukan bahwa ukuran perusahaan tidak berpengaruh terhadap manajemen laba. Besarnya aset perusahaan tidak memiliki pengaruh dalam terjadinya manajemen laba dalam perusahaan. Penelitian ini sejalan dengan penelitian yang dilakukan oleh Siregar dan Utama (2008) dan Guna dan Herawaty (2010) dimana ukuran perusahaan tidak memiliki pengaruh terhadap manajemen laba.

5. Pengaruh leverage terhadap manajemen laba

Hasil uji t (parsial) terkait variabel leverage menunjukan koefisien regresi sebesar 0.006 dan tingkat signifikansi sebesar 0.4410 yang menunjukan bahwa leverage tidak memiliki pengaruh terhadap manajemen laba. tinggi rendahnya besaran perbandingan antara total utang dengan total aset tidak memiliki pengaruh terhadap manajemen laba. ini berarti jika nilai leverage perusahaan kecil, hal ini disebabkan karena perusahaan lebih memilih melakukan pembiayaan dengan 
modal sendiri dibandingkan dengan utang dank arena perusahaan mengalami keuntungan dari setiap tahunnnya bukan karena melakukan manajemen laba, sebaliknya jika nilai leverage tinggi, maka hal itu disebabkan karena perusahaan lebih memilih melakukan pembiayaan dengan utang dibandingkan dengan modal sendiri. Penelitian ini tidak sejalan dengan penelitian yang dilakukan oleh Watts dan Zimmerman (1986), dan Guna dan Herawaty (2010) dimana leverage memiliki pengaruh negatif terhadap manajemen laba.

\section{SIMPULAN}

Berdasarkan hasil penelitian maka dapat diperoleh kesimpulan sebagai berikut :

1. Komite audit memiliki pengaruh negatif terhadap manajemen laba. Semakin besar komposisi komite audit yang memiliki latar belakang akuntansi dan keuangan maka dapat menekan tingkat manajemen laba. Komite audit yang berlatar belakang akuntansi dan keuangan mengetahui proses laporan keuangan perusahaan sehingga mampu mendeteksi adanya manajemen laba yang dilakukan oleh pihak manajemen perusahaan. Hal ini sesuai dengan uji hiptesis dimana komite audit berpengaruh negatif terhadap manajemen laba.

2. Komisaris independen tidak berpengaruh terhadap manajemen laba. Semakin besar proporsi komisaris independen tidak mempengaruhi tingkat manajemen laba perusahaan. Hal ini tidak sejalan dengan uji hipotesis dimana komisaris independen berpengaruh terhadap manajemen laba.

3. Ukuran KAP berpengaruh positif terhadap manajemen laba. Semakin baik kualitas auditor maka tingkat manajemen laba juga semakin tinggi. Hal ini dikarenakan berdasarkan sampel yang diteliti, perusahaan yang melakukan manajemen laba di audit oleh KAP big 4. Hasil penelitian ini tidak sejalan dengan uji hipotesis dimana ukuran KAP berpengaruh negatif terhadap manajemen laba.

\section{DAFTAR PUSTAKA}

Ali Irfan (2002). Pelaporan Keuangan dan Asimetri Informasi dalam Hubungan Agensi. Lintasan Ekonomi Vol. XIX. No.2. Juli 2002

Belkaoui, Ahmed Riahi. (2006). Accounting theory buku satu edisi 5. Jakarta: Salemba

empat. 
Boediono, Gideon. (2005). Kualitas laba: Studi pengaruh mekanisme corporate governance dan dampak manajemen laba dengan menggunakan analisis jalur. Simposium Nasional Akuntansi VIII.

Cornett, M. M., Marcus, A. J., and Tehranian, H. (2009). Corporate Governance And Earnings Management At Large U.S. Bank Holding Companies. Journal of Corporate Finance, 15, 412-430.

DeAngelo, L.E. (1981). Auditor Size and Audit Quality. Journal of Accounting and Economics, 3, 183-199.

Elder, J. Randal, Mark S. Beasley, Alvin Arens, dan Amir Abadi Yusuf . (2011). Jasa Audit dan Assurance. Jakarta: Salemba Empat

Freeman, E. (1984). Strategic Management.: A Stakeholder approach. Boston: Printman Press.

Ghozali, Imam. (2013). Aplikasi analisis multivariate dengan program IBM SPSS 21. Semarang: Badan Penerbit Universitas Dipenogoro

Ghozali, I. dan A. Chariri. (2007). Teori Akuntansi. Badan Penerbit Undip: Semarang Guna, W. I. and Herawaty, A. (2010). "Pengaruh Mekanisme Good Corporate Governance, Independensi Auditor, Kualitas Audit dan Faktor Lainnya Terhadap Manajemen Laba". Jurnal Bisnis Dan Akuntansi. 12(1): 53-68.

Habbash, Murya, Christoph Sindezingue dan Aly Salama.(2012). The effect of audit committee characteristics on earnings management: Evidence from the United Kingdom. International Journal of Disclosure and Governance Vol. 10, 1, 1338

Millstein, I.M. (1999). Introduction to the Report and Recommendations of the Blue Ribbon Committee on Improving The Effectiveness of Corporate Audit Committees. The Business Lawyer, 54 (May): 1057-1066

Nasution, Marihot dan Doddy Setiawan, (2007), " Pengaruh Corporate Governance terhadap Manajemen Laba di Industri Perbankan Indonesia", Simposium Nasional akuntansi X, Unhas Makassar, 26-28 Juli 2007.

Priyatno, Duwi. (2012). Belajar cepat olah data statistik dengan SPSS. Yogyakarta: Andi. 
Rustiarini, Ni wayan.(2012) Komite Audit dan Kualitas Audit Kajian Berdasarkan Karakteristik, Kompetensi dan Aktivitas Komite Audit. SNA 15 Banjarmasin 20-23 September 2012

Sawyer, B. Lawrence, Mortimer A. Dittenhofer, dan James H. Shreiner . (2006) . Internal Auditing .Jakarta : Salemba Empat

Schipper, Katherine. (1989). Comentary Katherine on Earnings Management. Accounting Horizon.

Setiawan, Teguh .2009. Analisis Pengaruh Mekanisme Good Corporate Governance Terhadap Praktek Manajemen Laba pada Perusahaan Manufaktur yang Terdaftar Di Bursa Efek Indonesia Periode 2005-2007. Jurnal Akuntansi Kontemporer, Vol 1 No.2. Juli 2009 Hal 99•122

Siallagan, Hamonangan dan Mas'ud Mahfoedz. (2006). Mekanisme corporate governance, kualitas laba dan nilai perusahaan. Simposium Nasional Akuntansi IX. Padang.

Siregar, S.V. and S. Utama. (2008). The Type of Earnings Management and the Effect of Ownership Structure, Firm Size, and Corporate-Governance Practices: Evidence from Indonesia. The International Journal of Accounting. 43, 1-27.

Sulistiawan, Dedhy, Yeni Januarsi, dan Liza Alvia. (2011). Creative Accounting. Jakarta : Salemba Empat

Sulistyanto, Sri H. (2008). Manajemen Laba: Teori dan Model Empiris. Jakarta: Grasindo

Sutedi, Adrian (2011) .Good Corporte Governance. Jakarta : Sinar Grafika

Stubben, Stephen R (2010). Discretionary Revenues as a Measure of Earnings Management The Accounting Review. Vol. 85, No. 2 PP. 695-717

Thiruvadi, Sheela dan Hua-Wei Huang. (2011). Audit committee gender differences and earnings management International Journal Vol. 26 No. 7, 2011 pp. 483 498

Wardhani, Ratna dan Herunata Joseph. (2010). Karakteristik Pribadi Komite Audit dan Praktik Manajemen Laba. Symposium Nasional Akuntansi XIII. Purwokerto.

Xie, Biao dan Wallace N Davidson III dan Peter 1 Dadalt. (2003). Earnings Management and Corporate Governance: The Role of Board and the Audit Committee. Journal of Corporate Finance. 9 (3): 295-316. 